\title{
Ekonomi Politikalarındaki Belirsizliklerin Güven Endeksleri Üzerindeki Etkisi
}

Saffet AKDAĞ

Makale Gönderim Tarihi: 08.06.2019

Makale Kabul Tarihi: 16.03.2020

\section{Öz}

Belirsizlikler toplumların karar süreçleri üzerinde etkili olan bir unsurdur. Özellikle ekonomi dünyasında var olan belirsizlikler toplumun hem tüketim hem de yatırım davranıșını yakından etkilemektedir. Bu bağlamda çalıșmada ekonomi politikalarındaki belirsizliklerin, toplumun ekonomiye güvenini temsil eden tüketici güven endeksi ve üretici güven endeksi üzerindeki etkisi araștırılmıștır. 13 OECD ülkesi ile 3 OECD üyesi olmayan 16 ülkenin Ocak 2003 ile Aralık 2018 tarihleri arasındaki aylık verileri kullanılarak panel nedensellik analizi gerçekleștirilmiștir. Panel nedensellik analiz sonuçlarına göre ekonomi politikalarındaki belirsizliklerin, güven endekslerinin nedeni olduğu tespit edilmiștir.

Anahtar Kelimeler: Ekonomik Politika Belirsizlik Endeksi, Güven Endeksi, Panel Nedensellik

Jel Kodları: C23, D80, E20, E27

\section{The Effects of Uncertainties in Economic Policy on Confidence Indices}

\section{Abstract}

Uncertainties are a factor that impact on decision-making processes of society. Especially the uncertainties in the world of economy closely affect both consumption behavior and investment behavior of the society. In this context, the effect of uncertainties in economic policies on consumer confidence index and producer confidence index representing the confidence of the society in the economy was investigated. Panel

1 Dr. Öğr. Üyesi, Tarsus Üniversitesi, Uygulamalı Bilimler Fakültesi, Finans ve Bankacılık Bölümü, saffetakdag@tarsus.edu.tr, Orcid ID: 0000-0001-9576-6786 
causality analysis was carried out between January 2003 and December 2018 for 16 OECD countries and 3 non-OECD countries. According to the results of causality analysis, it is determined that uncertainties in economic policies are the cause for confidence indices.

Key Words: Economy Policy Uncertainty Index, Confidence Index, Panel Causality

Jel Codes: C23, D80, E20, E27

\section{Giriș}

İnsanlar, kararlarının büyük çoğunluğunu belirsizlikler alında vermektedir. Bu nedenle belirsizliklerin, karar süreçleri üzerindeki etkisini belirlemek araștırmacıların ilgi odağı olmuștur (Liu, 2010, s. 1). Özellikle ekonomi alanındaki belirsizlikler toplumun her kesimini etkilemesi nedeniyle hem finansal otoriteler hem de piyasa oyuncuları tarafından dikkatle takip edilmektedir. Teorik olarak belirsizliklerin arttığı bir dönemde yatırımcılar açısından en iyi seçenek bekle ve gör politikasıdır. Dolayısıyla yatırımcılar belirsizliklerin olduğu ortamlarda yatırım kararlarını erteleyebilmektedirler. Bu durumdan da üretim ve istihdam olumsuz etkilenecektir.(Bernanke 1983; Bloom 2009). Diğer yandan belirsizlikler artıkça özellikle kredi sağlayan finansal kurumlar belirsizlik nedeniyle artan risk kaynaklı maliyetleri nedeniyle faiz oranlarını artıracaklar, faiz artıșı nedeniyle artan fon maliyetlerinin ise șirketlerin yatırım kararları üzerinde olumsuz etkileri olacaktır (Cerda vd., 2018, s. 2894). Nitekim 2008 yılındaki Büyük Buhran’ın büyüklüğü ve sürekliliği nedeniyle finansal piyasalarda ortaya çıkan belirsizlikler, tüm dünyada hem tüketicilerin harcama kararları üzerinde hem de ișletmelerin yatırım kararları üzerinde bekle gör politikası nedeniyle ciddi manada olumsuz etkilere neden olmuștur (Baker vd., 2012). Benzer șekilde AB ile İngiltere arasında ki Brexit belirsizliği, Trump önderliğindeki $A B D$ ekonomi politikalarındaki belirsizlikler, Rusya'nın küresel ekonomi içerisinde rol arayıșı, $A B D$ ve Avrupa Merkez Bankalarının para politikalarının öngörüsüzlüğü ve küresel çaptaki ticaret savașları, küresel çapta bir belirsizlik ortamının olușmasına katkı sağlamaya bașlamıștır (Yalçınkaya, 2019, s.57). Tüm bunlar, küresel ekonomik konjonktürde belirsizlik meydana getiren gelișmelerin bir risk unsuru olarak durduğunu göstermektedir. Zira küresel ölçekli belirsizlikler, finansal piyasalardaki dalgalanmaları arttırarak, sermaye akımlarını tersine çevirebilmekte, finansman kaynaklarına erișim 
imkanlarını kısıtlayarak yatırımlarının fırsat maliyetlerini artırabilmekte ve yatırımcıların risk iștahını azaltarak tüketim ve yatırım kararlarını sınırlandırabilmektedir (Rice, vd., 2018, s. 3). Bu yönüyle hem ulusal hem de uluslararası düzeyde ekonomi politikalarındaki belirsizlikler finans otoritelerince takip edilmektedir.

Ekonomi alanındaki belirsizliklerin büyük çoğunluğu finansal otoritelerin aldıkları ya da almadıkları kararlardan kaynaklanmaktadır. Bu kapsamda ekonomide meydana gelen belirsizlikleri ölçmek amacıyla çeșitli endeksler olușturulmaktadır. Bu endekslerden birisi olan ekonomik politika belirsizlik endeksi (EPU); Baker, Bloom ve Davis (2016) çalıșmasında geliștirilen ve medya içeriğinin analizine dayanan bir endekstir. Güven endeksleri ise ülkelerin ekonomik istikrarının önemli göstergelerinden biridir. Çünkü güven endeksleri toplumun ekonomiye olan güvenini göstermektedir. Aynı zamanda güven endeksleri, insanların kișisel mali durumları ve genel ekonomi hakkında düșündükleri iyimserlik veya karamsarlığı ifade eder. Endeksler mevcut durum kadar ekonominin gelecekteki durumunu da ifade edebilir (Van Dalen vd., 2018, s. 114). Özellikle ülkelerin uyguladıkları ekonomik programların bașarıya ulașmasında, toplumun tüm kesimlerinin, uygulanacak politikaların bașarılı olacağına dair güven duyması gerekmektedir. Bu nedenle politika yapıcılar bir yandan hedefledikleri amaçlara yönelik ekonomi politikaları uygularken diğer yandan toplumun güvenini kazanmaya yönelik uygulamalarda bulunmaktadır. Toplumun ekonomiye olan güveni ise hem tüketici hem de üretici güven endeksleri ile ölçülmektedir. Dolayısıyla güven endeksleri de piyasa otoriteleri ve yatırımcılar tarafından takip edilmektedir. Güven endeksleri üzerinde etkili olan faktörler ise akademik çalıșmalara da konu olmaktadır. Bu çalıșmada da öncelikli olarak ekonomi politikalarındaki belirsizliğin kamuoyu nezdinde gelecekteki ekonomi ile ilgili beklentiler üzerinde bir etkisinin olup olmadığı ölçülmeye çalıșılmıștır. Ceșitli ekonomik faktörlerin güven endeksleri üzerindeki etkisine yönelik gerçekleștirilen önceki çalıșmalardan farklı olarak bu çalıșmada ekonomi politikalarındaki belirsizliklerin güven endeksleri üzerinde bir etkisi olup olmadığının test edilmesi amaçlanmaktadır. Bu doğrultuda ekonomik politika belirsizliği endeksi hesaplanan, tüketici ve üretici güven endeksi verilerine ulașılan 16 ülkenin verileri kullanılarak değișkenler arasında bir nedensellik ilișkisi olup olmadığı, Dumitrescu ve Hurlin (2012) ile Emirmahmutoğlu ve Köse (2011) panel nedensellik analizleri ile test edilmiștir. Ekonomik politika belirsizlik endeksi ile hem tüketici güven endeksinin hem de üretici güven endeksinin birlikte 
kullanılması ve analizde kullanılan ülkeler bakımından çalıșma özgünlük arz etmekte olup bu yönüyle çalıșmanın literatüre katkı sağlaması beklenmektedir. Bu kapsamda çalıșma beș bölümden olușmaktadır. Illk bölümde giriș bașlığı alında belirsizlik kavramı ve belirsizliklerin ekonomi üzerindeki etkilerine dair bilgilere yer verilmiștir. İkinci bölümde ekonomi politikaları belirsizliği endeksi ile yapılan çalıșmaların yer aldığı literatür kısmı yer almaktadır. Üçüncü bölümde çalıșmada kullanılan veriler ve metodoloji tanıtılmıștır. Dördüncü bölümde analiz sonucu elde edilen bulgular yer almakta olup son bölümde bulgular yorumlanarak önerilerde bulunulmuștur.

\section{Literatür}

Politik, ekonomik ve diğer alanlarda ortaya çıkan belirsizliklerin, özellikle gelișmekte olan ülkelerin ekonomilerindeki birçok sektör ve gösterge üzerinde etkili olduğu bilinmektedir. Bu ilișkiyi, istatistikî olarak test eden öncü çalıșmalardan biri Carrière-Swallow ve Céspedes (2013) çalıșmasıdır. Illgili çalıșmada belirsizliklerin gelișmiș ve gelișmekte olan ülkelerin ekonomileri üzerindeki etkisi araștırılmıștır. Belirsizliklerde meydana gelen șokların gelișmekte olan ülkelerin ekonomilerini daha derinden ve daha uzun süreli etkilediği ifade edilmiștir. Ekonomik ve politik belirsizliklerin etkilerinin en yoğun görüldüğü sektörlerden biri de reel sektördür. Bu sonuca yönelik literatürde yer alan çalıșmalardan Ayaydın ve Karaaslan (2015) çalıșmasında Türkiye'de politik belirsizliklerin reel ekonomik sonuçlar üzerinde önemli bir etkiye sahip olduğu ifade edilmiștir. Danimarka'daki ekonomi politikalarındaki belirsizlikler ile tüketici güveni arasındaki ilișkiye yönelik gerçekleștirilen Van Dalen vd., (2016) çalıșmasında ise belirsizliklerin tüketici güveninin nedeni olduğu ifade edilmiștir. Ayrıca ekonomi politikalarındaki belirsizliklerin arıșının tüketici güveni üzerinde negatif etkisinin olduğu ifade edilmiștir. Akkuș (2017) çalıșmasında ise ABD'nin ekonomik politika belirsizlik endeksindeki artıșların, gelișmekte olan ülkelerdeki büyüme oranı üzerinde güçlü ve negatif bir etkiye sahip olduğu tespit edilmiștir. Șili özelinde gerçekleștirilen Cerda vd., (2017) çalıșmasında ekonomik belirsizlikteki bir artıșın; GSYiH, yatırım ve istihdamda bir düșüșe yol açtığı tespit edilmiștir. Albert ve Gómez Fernández (2018) çalıșmasında ise ekonomi politikalarındaki belirsizliklerinde meydana gelen șokların bașta güven endeksleri olmak üzere İspanya ekonomisi üzerinde olumsuz etkilerinin olduğu ifade edilmiștir. Caputo ve Duch, (2018) çalıșmasında ise $A B D^{\prime}$ deki ekonomi politikalarındaki belirsizliklerin hem ulusal hem de uluslararası piyasalarda yatırım, tasarruf ve tüketim kararları ile ilișkili 
olduğu ifade edilmiștir. Ayrıca ekonomi politikalarındaki belirsizliklerin tüketici davranıșlarını negatif etkilediği ifade edilmiștir. Hardouvelis vd., (2018) çalıșmasında ise küresel ekonomik politika belirsizliklerindeki șokların Yunanistan'ın ekonomik aktivite, yatırım, sınai üretim endeksi, istihdam, ekonomik duyarlılık, borsa ve hane halkı mevduat davranıșları ile negatif ilișkili ve tahvil getirileri ile olumlu yönde ilișkili olduğu ifade edilmiștir. Korkmaz ve Güngör (2018) çalıșmasında küresel ekonomik politika belirsizliğinin Borsa İstanbul'da ișlem gören seçilmiș șirketlerin hisse senetlerinin getirilerindeki oynaklık üzerindeki etkisinin istatistiksel açıdan anlamlı ve pozitif olduğu tespit edilmiștir. Perić ve Sorić'in (2018) ekonomi politikası belirsizliği endeksi ile tüketici güven endeksi arasındaki nedensellik ilișkisi olup olmadığının tespitine yönelik çalıșmasında, ekonomik politika belirsizlik endeksinden tüketici güvenine doğru nedenselliğin Çin, İtalya, Kore ve İngiltere için geçerli olduğu ifade edilmiștir. Güney Afrika özelinde gerçekleștirilen Redl (2018) çalıșmasında makroekonomik belirsizlik ile tüketici güven endeksi arasında negatif ilișki olduğu ifade edilmiștir. Șahinöz ve Coșar (2018) çalıșmasında ise belirsizliklerdeki artıșın Türkiye'nin ekonomik büyüme, yatırım ve tüketim harcamaları üzerinde negatif etkileri olduğu ifade edilmiștir. Benzer șekilde Türkiye özelinde gerçekleștirilen Bilgin vd., (2019) çalıșmasında ise Türkiye için hesaplanan ekonomi politikası belirsizlik endeksinin güven endeksleri ile negatif ilișkili olduğu ifade edilmiștir. Yalçınkaya (2019) çalıșmasında ise küresel ekonomik, politik ve jeopolitik gelișmelerden kaynaklı belirsizliklerin, kısa ve/veya uzun dönemde Türkiye ekonomisinin finansal ve mali nitelikli makroekonomik göstergeleri üzerinde önemli ölçüde ve beklentilerle uyumlu olarak olumsuz etkiler yaratığı belirlenmiștir.

\section{Veri ve Metodoloji}

Çalıșmada 16 ülkenin Ocak 2003 ile Aralık 2018 tarihleri arasında aylık olarak ekonomik politika belirsizlik endeksi ile tüketici güven endeksi ve üretici güven endeksi verileri kullanılmıștır. Ekonomik politika belirsizlik endeksi 23 ülke için hesaplanmaktadır. Ancak bu 23 ülkenin 16'sının üretici ve tüketici güven endeksine ulașılmıștır. Bu nedenle analiz 16 (ABD, Almanya, Avustralya, Brezilya, Çin, Fransa, Hollanda, İngiltere, İrlanda, İspanya, İsveç, İtalya, Japonya, Meksika ve Rusya) ülke ile sınırlandırılmıștır. Bu 16 ülke için en geniș veri aralığı ise Ocak 2003 ile Aralık 2018 tarihleri arasında gerçekleștiği için analizde ilgili tarihler arasındaki veriler kullanılmıștır. Ekonomik politika belirsizlik endeksi Baker vd., (2016) çalıșmasında geliștirilen yöntem ile bașta küre- 
sel ekonomik politika belirsizliği endeksi olmak üzere 23 ülke için ayrı hesaplanmakta ve aylık olarak yayınlanmaktadır. İlgili endeks ülkelerin ulusal gazeteleri taranıp çeșitli anahtar kelimeler dikkate alınarak hesaplanmaktadır.

Tüketici güven göstergesi ise ailelerin, beklenen finansal durumlara, genel ekonomik durum, ișsizlik ve tasarruf kabiliyetlerine ilișkin duyarlılıklarına bağlı olarak șekillenen tüketim ve tasarruflarındaki gelișmelerin bir göstergesidir. 100'ün üzerindeki bir gösterge, tüketicilerin gelecekteki ekonomik duruma yönelik güvenlerinin artmasının bir sonucu olarak ortaya çıkmakta ve bunun sonucunda tasarruf etmeye daha az eğilimli olduğunu ve gelecek 12 aylık dönemde büyük alımlar için para harcama eğilimi içinde olacağını göstermektedir. 100'ün altındaki değerler ise gelecekte ekonomideki gelișmelere karșı karamsar bir tutuma ișaret etmekte olup, tüketicilerin muhtemelen daha fazla tasarruf etme ve daha az tüketme eğilimi içinde olduğunu göstermektedir (OECD). Üretici güven endeksi sektördeki üretim, sipariș ve ișlenmiș ürün stoklarındaki gelișmelere ilișkin görüș anketlerine dayanarak gelecekteki gelișmelere ilișkin bilgi sağlayarak, çıkı büyümesini izlemek ve ekonomik aktivitede dönüm noktaları öngörmek için kullanılabilmektedir. 100'ün üzerindeki rakamlar, yakın gelecekteki iș performansına olan güvende bir artıșa ișaret ederken, 100'ün altındaki rakamlar gelecekteki performansa karșı karamsarlığa ișaret etmektedir (OECD). Ekonomik politika belirsizlik endeksi verileri http://www.policyuncertainty.com internet sitesinden, tüketici güven endeksi ile üretici güven endeksi ise OECD’nin internet sitesinden alınmıștır.

Çalıșmada birim kök ve nedensellik analizleri öncesinde değișkenler için yatay kesit bağımlılığı ve homojenlik testleri gerçekleștirilmiștir. Yatay kesit bağımlılığı ve homojenlik test sonuçları analizde kullanılacak birim kök testleri ve nedensellik testlerinin seçilmesinde önem arz etmektedir. Yatay kesit bağımlılığı için yatay kesitler (ülkeler) arasındaki bağımlılığın olup olmadığı Breusch ve Pagan (1980) çalıșmasında geliștirilen LM (Lagrange Multiplier) testi ve Pesaran (2004) çalıșmasında geliștirilen $C D_{L M^{\prime}} C D$, testi ve Pesaran vd., (2008) çalıșmasında geliștirilen $L M_{\text {adj }}$ testi ile test edilmiștir. $C D$ ve $C D_{L M}$ testleri yatay kesit boyutunun zaman boyutundan büyük olması durumunda tercih edilirken, $L M$ ve $L M_{\text {adi }}$ testleri zaman boyutunun yatay kesit boyutundan büyük olduğu durumlarda tercih edilmektedir (Menyah vd., 2014; Kar vd., 2011). Pesaran ve Yamagata (2008) çalıșmasında geliștirilen Slope Homogeneity testi ile açıklayıcı değișkenin katsayılarının bir yatay kesitten diğerine 
değișip değișmediği test edilmiștir. Yatay kesit bağımlılığı ve homojenlik test sonuçlarına göre verilerin durağan olup olmadığını belirlemek amacıyla ikinci nesil birim kök testleri Hadri ve Kurozumi (2012) ile Pesaran (2007) çalıșmasında geliștirilen CADF kullanılmıștır. Hadri ve Kurozumi (2012) birim kök testi KPSS birim kök testinin panele uyarlanmıș halidir. Teste boș hipotez serilerin durağan olduğunu, alternatif hipotez ise serilerin durağan olmadığını göstermektedir. Pesaran (2007) çalıșmasında geliștirilen CADF testi ise yatay kesit bağımlılığı varsayımında tercih edilmektedir. CADF testi hem $\mathrm{N}>\mathrm{T}$ hem de $\mathrm{T}>\mathrm{N}$ durumunda kullanılabilmektedir (Pesaran, 2007, s. 269).

Çalıșmada panelin geneli için değișkenler arasındaki nedensellik ilișkisi Dumitrescu ve Hurlin (2012) çalıșmasında geliștirilen panel nedensellik analizi ile her bir yatay kesit için sonuçları veren Emirmahmutoğlu ve Köse (2011) çalıșmasında geliștirilen nedensellik analizi kullanılmıștır. Yatay kesit bağımlılığı ve heterojenlik varsayıma dayalı Dumitrescu ve Hurlin (2012) panel nedensellik analizi Wald istatistiklerine dayalı bir test olup zaman boyutunun (T) yatay kesit boyutundan (N) büyük ya da küçük olması durumunda da kullanılabilmektedir. Dumitrescu ve Hurlin (2012) panel nedensellik analizinde yatay kesitlerde nedensellik ilișkisinin olmadığı temel hipoteze karșı en az bir yatay kesitte nedensellik ilișkinin olduğunu ifade eden alternatif hipotez test edilmektedir. $x$ ve y gibi iki değișkenin durağan olması șartıyla $N$ sayıda yatay kesitin ve $T$ dönem içinde $t$ dönemin herbir değeri için temel alınan model așağıdaki gibidir (Dumitrescu ve Hurlin, 2012, s. 1451).

$$
y_{i, t}=\alpha_{i}+\sum_{k=1}^{K} \gamma_{i}^{(k)} y_{i, t-k}+\sum_{k=1}^{K} \beta_{i}^{(k)} x_{i, t-k}+\varepsilon_{i, t}
$$

Dumitrescu ve Hurlin'i (2012) sıfır hipotezini test etmek için ilk olarak her bir yatay kesit için bireysel Wald istatistikleri hesaplanır. Bu istatistikler her kesit için nedensellik ilișkisini vermektedir. Daha sonra panel için geçerli olan Wald istatistiği $\left(W_{N, T}^{H n c}\right)$, bireysel Wald istatistiklerinin ortalaması alınarak elde edilir ve așağıdaki șekilde gösterilebilir (Dumitrescu ve Hurlin, 2012, s. 1453).

$$
W_{N, T}^{H n c}=\frac{1}{N} \sum_{i=1}^{N} W_{i, T}
$$

Dumitrescu ve Hurlin (2012) çalıșmasında zaman boyutunun yatay kesit boyutundan büyük olması durumunda $(T>N)$ kullanılmasını 
önerdiği standardize edilmiș test istatistiği ise așağıda gösterilmiștir (Dumitrescu ve Hurlin, 2012, s. 1453).

Eğer $(T>N)$ ise

$$
Z_{N, T}^{H n c}=\sqrt{\frac{N}{2 K}}\left(W_{N, T}^{H n c}-K\right) \rightarrow_{T, N \rightarrow \infty}^{d} N(0,1)
$$

Todo-Yamamato(1995) nedensellik testinin panele uyarlanmıș hâli olan ve Fisher (1932) çalıșmasında geliștirilmiș olan meta analizini kullanan Emirmahmutoğlu ve Köse (2011) nedensellik analizi değișkenler aynı seviyede durağan olmasa bile kullanılmaktadır. Bu testin bir diğer avantajı ise yatay kesit bağımlılığını da dikkate alması ve eșbütünleșme ilișkisi tespit edilemese de kullanılabilmesidir (Emirmahmutoğlu ve Köse, 2011 1). Test aynı zamanda heterojen bir yapıya sahip olduğundan hem panelin geneli hem de her bir yatay kesit için sonuçlar verebilmektedir (Kurt ve Köse, 2017, s. 306). Bu testte iki değișkenli VAR modeline dayalı nedensellik ilișkisi gösteren denklemler (4 ve 5) așağıdaki gibi kurulabilmektedir (Emirmahmutoğlu ve Köse, 2011, s. 872).

$$
\begin{aligned}
& x_{i, t}=\mu_{i}^{x}+\sum_{j=1}^{k_{i}+\operatorname{dmax}_{i}} A_{11, i j} x_{i, t-j}+\sum_{j=1}^{k_{i}+\max _{i}} A_{12, i j} y_{i, t-j}+\mu_{i, t}^{x} \\
& y_{i, t}=\mu_{i}^{y}+\sum_{j=1}^{k_{i}+\operatorname{dmax}_{i}} A_{21, i j} x_{i, t-j}+\sum_{j=1}^{k_{i}+d \max _{i}} A_{22, i j} y_{i, t-j}+\mu_{i, t}^{y} \\
& i=1,2, \ldots, \mathrm{N} \text { ve } j=1,2, \ldots, k
\end{aligned}
$$

$x_{i}$ ve $y_{i}$ değișkenleri, $\mu_{i}$ hata terimini, $A$ sabit etkiler matrisini, $k_{i}$ gecikmeyi, $d \max _{i}$ her yatay kesit için maksimum entegresyon değeri, $i$ yatay kesitleri, $t$ zaman periyodunu ifade etmektedir.

\section{Bulgular}

Çalıșmada kullanılan ekonomik politika belirsizlik (EPU) endeksi ile tüketici güven endeksi (TGE) ve üretici güven endeksi (ÜGE) verileri logaritması alınarak analizde kullanılmıștır. Illgili verilerin tanımlayıcı istatistikleri Tablo 1'de verilmiștir. 
Tablo 1: Tanımlayıcı İstatistikler

\begin{tabular}{lcccc}
\hline Değișkenler & Ortalama & Maksimum & Minimum & Standart Hata \\
\hline InEPU & 4.679 & 6.841 & 2.141 & 0.546 \\
InTGE & 4.604 & 4.649 & 4.535 & 0.015 \\
InÜGE & 4.607 & 4.648 & 4.484 & 0.014 \\
\hline
\end{tabular}

Tablo 1'de yer alan tanımlayıcı istatistikler değerlendirildiğinde ekonomi politikası belirsizlik endeksindeki oynaklığın güven endekslerindeki oynaklıktan daha yüksek olduğu görülmektedir. Veriler üzerinde gerçekleștirilecek birim kök testleri öncesinde yatay kesit bağımlılığı ve homojenlik testleri gerçekleștirilmiștir. Her iki test sonuçlarına göre kullanılacak birim kök ve nedensellik testlerinin seçimi önem arz etmektedir. Değișkenlere ilișkin yatay kesit bağımlılığı ve homojenlik test sonuçları Tablo 2'de verilmiștir.

Tablo 2: Yatay Kesit Bağımlılığı ve Homojenite Test Sonuçları

\begin{tabular}{|c|c|c|}
\hline Test & $\begin{array}{c}\text { (InTGE = f (InEPU) } \\
\text { İstatistik Değeri }\end{array}$ & $\begin{array}{c}\text { InÜGE = f (lnEPU) } \\
\text { İstatistik Değeri }\end{array}$ \\
\hline$L M$ & $2981.660 *(0.000)$ & $2361.041 *(0.000)$ \\
\hline$C D_{L M}$ & $184.719 *(0.000)$ & $144.659 *(0.000)$ \\
\hline$C D$ & $2.284^{*}(0.000)$ & $18.604 *(0.000)$ \\
\hline$L M_{\text {adj. }}$ & $108.420 *(0.000)$ & $108.861 *(0.000)$ \\
\hline$\breve{\Delta}$ & $12.443^{*}(0.000)$ & $238.615^{*}(0.000)$ \\
\hline$\breve{\Delta}_{\text {adj. }}$. & $12.574^{*}(0.000)$ & $241.127 *(0.000)$ \\
\hline
\end{tabular}

*\%1 önem seviyesinde anlamlıdır. Parantez içindeki değerler olasılık değerlerini göstermektedir.

Tablo 2'de yer alan yatay kesit bağımlılığı testi sonuçlarına göre, yatay kesit bağımlılığının olmadığını ifade eden sıfır hipotezi, \% 1 anlamlılık düzeyinde reddedilmektedir. İlgili test sonuçlarına göre yatay kesiti olușturan ülkelerin serileri birbirlerini etkilemektedir. Tablo 2'de eğim katsayısının homojen olup olmadığı da test edilmiștir. Illgili testlerden elde edilen sonuçlara göre \% 1 anlamlılık düzeyinde eğim katsayısının homojen olduğu hipotezi reddedilmektedir. Verilerin durağan olup olmadığını belirlemek için gerçekleștirilen birim kök test sonuçları Tablo $3^{\prime}$ te verilmiștir. 
Tablo 3: Birim Kök Test Sonuçları

\begin{tabular}{lllll}
\hline \multirow{2}{*}{ Değișkenler } & \multicolumn{2}{l}{ Hadri-Kurozumi Testi (ZA_s) } & CADF & \\
& Sabit & Sabit ve Trendli & Sabit & Sabit ve Trendli \\
\hline $\ln E P U$ & $-3.8899(0.9988)$ & $-4.7297(0.9998)$ & $-5.449 *(0.0000)$ & $-5.903^{*}(0.0000)$ \\
$\ln T G E$ & $-1.9824(0.9763)$ & $-2.1423(0.9839)$ & $-3.651^{*}(0.0000)$ & $-3.954^{*}(0.0000)$ \\
$\ln$ ÜGE & $-2.5931(0.9952)$ & $-2.2520(0.9878)$ & $-4.177^{*}(0.0000)$ & $-4.766^{*}(0.0000)$ \\
\hline
\end{tabular}

*\%1 önem seviyesinde anlamlıdır. Parantez içindeki değerler olasılık değerlerini göstermektedir. Maksimum gecikme sayısı 12 alınmıștır. Optimal gecikme uzunlukları AIC (Akaike Information Criterion) kriterine göre belirlenmiștir.

Tablo 3'te yer alan Hadri-Kurozumi ve CADF birim kök test sonuçlarına göre verilerin düzeyde durağan olduğu tespit edilmiștir. Bu sonuçlara göre değișkenlerin düzey değerleri kullanılarak nedensellik analizi gerçekleștirilebilir. Tablo $4^{\prime}$ te ekonomik politika belirsizlik endeksinden güven endekslerine doğru Dumitrescu ve Hurlin (2012) panel nedensellik test sonuçları verilmiștir.

Tablo 4: Dumitrescu ve Hurlin (2012) Panel Nedensellik Sonuçları

\begin{tabular}{cccc}
\hline $\begin{array}{c}\text { Nedenselliğin } \\
\text { Yönü }\end{array}$ & $\begin{array}{c}\text { W-Bar Test } \\
\text { İstatistiği }\end{array}$ & $\begin{array}{c}\text { Z-BarTest } \\
\text { istatistiği }\end{array}$ & Olasılık Değeri \\
\hline $\ln E P U \rightarrow \ln T G E$ & 3.566 & 3.021 & 0.0025 \\
$\ln E P U \rightarrow \ln U ̈ G E$ & 2.426 & 3.928 & 0.0000 \\
\hline
\end{tabular}

*\%1 önem seviyesinde anlamlıdır.

Tablo 4'te yer alan panel nedensellik test sonuçlarına göre ekonomik politika belirsizlik endeksinin hem tüketici hem de üretici güven endeksinin nedeni olduğu tespit edilmiștir. Tablo $5^{\prime}$ te ise değișkenler arasındaki nedensellik ilișkisinin her bir yatay kesit için var olup olmadığını belirlemek amacıyla gerçekleștirilen Emirmahmutoğlu ve Köse (2011) nedensellik testi sonuçları yer almaktadır.

Tablo 5: Emirmahmutoğlu ve Köse Panel Nedensellik Sonuçları

\begin{tabular}{lclccc}
\hline & InEPU $\rightarrow \operatorname{lnTGE}$ & \multicolumn{3}{c}{$\operatorname{lnEPU~} \rightarrow \operatorname{lnÜGE}$} \\
\hline Ülkeler & Test İstatistiği & $\begin{array}{c}\text { Olasılık } \\
\text { Değeri }\end{array}$ & Ülkeler & Test İstatistiği & $\begin{array}{c}\text { Olasılık } \\
\text { Değeri }\end{array}$ \\
ABD & 7.652 & 0.105 & ABD & 6.544 & 0.162 \\
Almanya & $21.852^{*}$ & 0.000 & Almanya & 4.400 & 0.355 \\
Avustralya & 7.968 & 0.240 & Avustralya & 7.623 & 0.367 \\
Brezilya & $10.517^{* *}$ & 0.033 & Brezilya & $16.909^{*}$ & 0.002
\end{tabular}




\begin{tabular}{|c|c|c|c|c|c|}
\hline Çin & 6.179 & 0.289 & Çin & 5.201 & 0.267 \\
\hline Fransa & 2.594 & 0.628 & Fransa & 3.872 & 0.424 \\
\hline $\begin{array}{l}\text { Güney } \\
\text { Kore }\end{array}$ & $11.141^{* *}$ & 0.025 & $\begin{array}{l}\text { Güney } \\
\text { Kore }\end{array}$ & 3.484 & 0.480 \\
\hline Hollanda & $13.749 *$ & 0.008 & Hollanda & $16.145^{*}$ & 0.001 \\
\hline İngiltere & 3.356 & 0.500 & İngiltere & 1.920 & 0.589 \\
\hline İrlanda & 0.703 & 0.951 & İrlanda & 1.204 & 0.878 \\
\hline İspanya & 2.464 & 0.651 & İspanya & 1.723 & 0.632 \\
\hline İsveç & $21.995^{* *}$ & 0.038 & İsveç & 2.536 & 0.469 \\
\hline İtalya & $9.373 * *$ & 0.050 & İtalya & 4.536 & 0.338 \\
\hline Japonya & $14.848 * * *$ & 0.095 & Japonya & 3.338 & 0.503 \\
\hline Meksika & 2.555 & 0.635 & Meksika & $11.632^{*}$ & 0.009 \\
\hline Rusya & 16.980 & 0.150 & Rusya & 0.244 & 0.970 \\
\hline
\end{tabular}

$* \% 1, * * \% 5$ ve ***\%10 önem seviyesinde anlamlıdır.

Tablo 5'te yer alan Emirmahmutoğlu ve Köse (2011) panel nedensellik test sonuçlarına göre ekonomik politika belirsizlik endeksinden tüketici güven endeksine doğru nedenselliğin Almanya, Brezilya, Güney Kore, Hollanda, İsveç, İtalya ve Japonya için geçerli olduğu tespit edilmiștir. Ekonomik politika belirsizlik endeksinden üretici güven endeksine doğru nedenselliğin ise Brezilya, Hollanda ve Meksika ülkeleri için geçerli olduğu tespit edilmiștir.

\section{Sonuçlar}

Belirsizlikler bireylerin karar süreçlerinde en etkili olan kavramlardan biridir. Cünkü belirsizliklerin arttığı dönemlerde bireyler bekle gör politikası nedeniyle hem tüketim hem de yatırım kararlarını erteleyebilmektedirler. Dolayısıyla ertelenen bu kararların da ekonomi üzerinde olumsuz sonuçlar doğurması beklenmektedir. Bu çalıșmada da ekonomi politikalarındaki belirsizliklerin bireylerin tüketim ve yatırım kararları üzerinde nasıl bir etki yarattığının test edilmesi amaçlanmıștır. Bu bağlamda Baker vd., (2016) çalıșmasıyla olușturulan 16 ülkenin ekonomik politika belirsizlik endeksi ile tüketici ve üretici güven endeksinin Ocak 2003 ile Aralık 2018 tarihleri arasındaki aylık verileri kullanılarak Dumitrescu ve Hurlin (2012) ile Emirmahmutoğlu ve Köse (2011) panel nedensellik analizleri kullanılmıștır. Dumitrescu ve Hurlin (2012) panel nedensellik analiz sonuçlarına göre ekonomik politik belirsizlik endeksinden güven endekslerine doğru bir nedensellik ilișkisi tespit edilmiștir. Emirmahmutoğlu ve Köse (2011) panel nedensellik analizi sonuçlarına göre ise eko- 
nomik politika belirsizlik endeksinden tüketici güven endeksine doğru nedenselliğin Almanya, Brezilya, Güney Kore, Hollanda, İsveç, İtalya ve Japonya için, ekonomik politika belirsizlik endeksinden üretici güven endeksine doğru nedenselliğin ise Brezilya, Hollanda ve Meksika için geçerli olduğu tespit edilmiștir. Çalıșma sonuçları Danimarka özelinde yapılan Van Dalen vd., (2016) çalıșması, Yunanistan özelinde yapılan Hardouvelis vd., (2018) çalıșması, Türkiye özelinde yapılan Șahinöz ve Coșar (2018), Bilgin vd., (2019) ve Yalçınkaya (2019) çalıșmaları ve birden fazla ülke için gerçekleștirilen Caputo ve Duch, (2018) ve Perić ve Sorić'in (2018) çalıșmalarıyla örtüșmektedir.

Çalıșmadan elde edilen sonuçlar değerlendirildiğinde ekonomi politikalarındaki belirsizlikler ile hem tüketici hem de üreticilerin ekonomiye güven duygusu arasında bir nedensellik ilișkisi olduğu tespit edilmiștir. Ekonomide yașanan belirsizlikler hem tüketicilerin hem de üreticilerin ekonomiye olan güven duygusunu etkilemektedir. Dolayısıyla toplumun ekonomiye güveninde ortaya çıkacak olumsuz gelișmeler ülkelerin ekonomik açıdan istikrara kavușmasını zorlaștıracaktır. Bu nedenle piyasa otoritelerince toplumun ekonomiye olan güveninin azalmaması için atılması gereken önemli adımlardan biri de ekonomi politikalarındaki belirsizliklerin giderilmesidir. Bu nedenle daha șeffaf ekonomi politikalarının benimsenmesi, belirsizlik doğuracak uygulamalardan kaçınılması, proaktif bir yaklașımla piyasalarda olușabilecek belirsizliklerin giderilmesinin, toplumun ekonomiye olan güven duygusuna pozitif katkı sağlayacağı düșünülmektedir. Ayrıca kamu otoritelerince özellikle yazılı ve görsel ve hatta sosyal medyayı etkin bir șekilde kullanarak kamuoyunu aydınlatması ve belirsizlik içeren haber ve içeriklerin gözden geçirilerek kamuoyu açıklamaları ile giderilmesi önerilebilir. Böylelikle toplumun ekonomiye olan güven kaybının önüne geçilerek, ülke ekonomilerinin istikrarlı bir yapıya kavușmasına katkı sağlayacaktır.

Çalıșma, hem 16 ülke üzerinde gerçekleștirilmiș olması, hem ekonomi politikalarındaki belirsizliklerin toplumun tüm kesimini temsil eden tüketici ve üreticilerin güveni üzerindeki sonuçlarını ortaya koyması bakımından literatüre özgün bir katkı sağlayacaktır. Bundan sonra yapılacak benzer çalıșmalarda, farklı güven endekslerinin de modele dâhil edilmesi ve daha sofistike yöntemler kullanılması literatüre katkı sağlaması bakımından önerilmektedir. Ayrıca ülkelere özgü sonuçların nedenleri yeni çalıșmaların konusunu olușturabilir. 


\section{KAYNAKÇA}

Akkuș, Ö. (2017). Ekonomik Politika Belirsizliği ve Politik İstikrarsızlı̆ın Büyüme Üzerindeki Etkisi. Anadolu Üniversitesi Sosyal Bilimler Dergisi, 17(3), 27-42.

Albert, J. F., \& Gómez Fernández, N. (2018). The Impact of Uncertainty Shocks in Spain: SVAR Approach with Sign Restrictions. Cañada Blanch Centre for Contemporary Spanish Studies Working Paper, FPU16/03957.

Ayaydın, H., \& Karaaslan, i. (2015). Politik Belirsizlikler ve Finansal Performans: BIST Örneği. Gümüșhane Üniversitesi Sosyal Bilimler Enstitüsü Elektronik Dergisi, 6(13), 51-63.

Baker, S. R., Bloom, N., \& Davis, S. J. (2016). Measuring Economic Policy Uncertainty. The Quarterly Journal of Economics, $131(4), 1593-1636$.

Bilgin, M. H., Demir, E., Gozgor, G., Karabulut, G., \& Kaya, H. (2019). A New Method to Measure Economic and Financial Uncertainty in Turkey. Available at SSRN 3337913.

Breusch, T. S., \& Pagan, A.R.(1980). The Lagrange Multiplier Test and Its Applications to Model Specification in Econometrics. Review of Economic Studies, 47, 239-253.

Caputo, R., \& Duch, R. M. (2018). US Economic Policy Uncertainty is Presidential. Nuffield College Centre for Experimental Social Sciences (CESS), Working Paper Series.

Carrière-Swallow, Y., \& Céspedes, L.F. (2013). The impact of Uncertainty Shocks in Emerging Economies. Journal of International Economics, 90(2), 316-325.

Cerda, R., Silva, Á., \& Valente, J. T. (2018). Impact of Economic Uncertainty in A Small Open Economy: The Case of Chile. Applied Economics, 50(26), 2894-2908.

Dumitrescu, E. I., \& Hurlin, C. (2012). Testing for Granger Non-Causality in Heterogeneous Panels. Economic Modelling, 29(4), 1450-1460.

Emirmahmutoğlu, F. \& Köse, N. (2011). Testing for Granger Causality in Heterogeneous Mixed Panels. Economic Modelling, 28(3), 870-876.

Fisher, R.A. (1932), Statistical Methods for Research Workers, (4. Edition), Edinburgh: Oliver and Boyd.

Hadri, K., \& Kurozumi, E. (2012). A Simple Panel Stationarity Test in The Presence of Serial Correlation and A Common Factor. Economics Letters, 115(1), 31-34.

Hardouvelis, G. A., Karalas, G., Karanastasis, D., \& Samartzis, P. (2018). Economic Policy Uncertainty, Political Uncertainty and The Greek Economic Crisis. https:// papers.ssrn.com/sol3/papers.cfm?abstract_id=3155172.

Im, K.S, Pesaran, M.H., \& Shin, Y. (2003). Testing for Unit Roots in Heterogeneous Panels. Journal of Econometrics, 115, 53-74.

Kar, M., Nazlıoğlu, Ș., \& Ağır, H. (2011). Financial Development and Economic Growth Nexus in the MENA Countries: Bootstrap Panel Granger Causality Analysis. Economic Modelling, 28(1-2), 685-693. 
Korkmaz, Ö., \& Güngör, S. (2018). Küresel Ekonomi Politika Belirsizliğinin Borsa İstanbul'da İșlem Gören Seçilmiș Endeks Getirileri Üzerindeki Etkisi. Anemon Muș Alparslan Üniversitesi Sosyal Bilimler Dergisi, 6, 211 1-219.

Kurt, G., \& Köse, A. (2017). Türkiye'de Bankaların Finansal Oranları Ile Hisse Senedi Getirisi Arasındaki Panel Nedensellik ilișkisi. Çukurova Üniversitesi Sosyal Bilimler Enstitüsü Dergisi, 26(3), 302-312.

Levin, A., Lin, C. \& Chu, C.J. (2002). Unit Root Tests in Panel Data: Asymptotic and Finitesample Properties. Journal of Econometrics, 108, 1-24.

Liu, B. (2010). Uncertainty Theory. In Uncertainty Theory. Berlin, Heidelberg: Springer.

Menyah, K., Nazlioglu, S., \& Wolde-Rufael, Y. (2014). Financial Development, Trade Openness and Economic Growth in African Countries: New Insights from a Panel Causality Approach. Economic Modelling, 37, 386-394.

Perić, B. Š., \& Sorić, P. (2018). A note on the "Economic Policy Uncertainty Index". Social Indicators Research, 137(2), 505-526.

Pesaran, H., M., (2004). General Diagnostic Tests for Cross Section Dependence in Panels. Working Paper, 0435, University of Cambridge.

Pesaran, H., M., (2007). A Simple Panel Unitroot Test in the Presence Of Cross-Section Dependence. Journal of Applied Economics, 22, 265-312.

Pesaran, H., M., \& Yamagata, T. (2008). Testing Slope Homogeneity in Large Panels. Journal of Econometrics, 142, 50-93.

Redl, C. (2018). Macroeconomic Uncertainty in South Africa. South African Journal of Economics, 86(3), 361-380.

Rice, A., Vehbi, T., \& Wong, B. (2018). Measuring Uncertainty and Its Impact on the New Zealand Economy. Reserve Bank of New Zealand Analytical Note Series, No: AN2018/01, 1-19.

Șahinoz, S., \& Coșar, E. E. (2018). Quantifying Uncertainty and Identifying Its Impacts on the Turkish Economy. Empirica, 1-23.

Toda, H. Y., \& Yamamoto, T. (1995). Statistical Inference in Vector Autoregressions with Possibly Integrated Processes. Journal of Econometrics, 66(1-2), 225-250.

Van Dalen, A., De Vreese, C. H., \& AlbAEk, E. (2016). Mediated Uncertainty: The Negative Impact of Uncertainty in Economic News on Consumer Confidence. Public Opinion Quarterly, 81 (1), 111-130.

Yalçınkaya, Ö. (2019). Küresel Ekonomik, Politik ve Jeopolitik Belirsizliklerin Makroekonomik Etkileri: Türkiye Ekonomisi Üzerine SVAR Analizi (1992: Q1-2018Q: 2). Journal of Yasar University, 14(53), 56-73. 